\title{
Production and localization of activins and activin type IIA and IIB receptors by the human endosalpinx
}

\author{
B A Refaat, A O Bahathiq, S Sockanathan, R L Stewart ${ }^{1}, M$ Wells ${ }^{1}$ and W L Ledger \\ Section of Reproductive and Developmental Medicine, University of Sheffield, Level 4, The Jessop Wing, \\ Royal Hallamshire Hospital, Sheffield S10 2SF, UK and ${ }^{1}$ Division of Genomic Medicine, Section of Oncology and \\ Pathology, University of Sheffield Medical School, Beech Hill Road, Sheffield S10 2RX, UK
}

Correspondence should be addressed to W L Ledger; Email: W.Ledger@Sheffield.ac.uk

\begin{abstract}
Fallopian tubes from ten premenopausal women were collected and examined for the presence of inhibin, activin and its type IIA and IIB receptors (ActRIIA and ActRIIB) in the endosalpinx. Immunocytochemistry demonstrated clear staining for the $\beta A, \beta B$ subunits and ActRIIA and ActRIIB that increased in intensity from the isthmus to the ampulla. No staining for the $\alpha$ subunit was observed. Whilst the staining of the $\beta A$ subunit and ActRIIA was seen in almost every epithelial cell, staining for the $\beta B$ subunit and ActRIIB was more variable. In situ hybridization and RT-PCR confirmed the presence of $m$ RNA for the $\beta A$, $\beta B$ subunits and ActRIIA and ActRIIB. These results indicated that the epithelium of the uterine tube is able to synthesize activin but not inhibin and has receptors for activin. Activins may thus act as paracrine regulators of tubal epithelial cell function, and embryonic activity may also bind to epithelial receptor and initiate intracellular processes that alter epithelial cell secretions.

Reproduction (2004) 128 249-255
\end{abstract}

\section{Introduction}

Activins and inhibins are members of a family of related growth factors called the transforming growth factor- $\beta$ superfamily (TGF- $\beta$ ) (Massagué 1990). Activins and inhibins were identified initially as gonadal proteins which have a stimulating (activins) and suppressing (inhibins) effect on follicle-stimulating hormone ( $\mathrm{FSH})$ production in cultured rat anterior pituitary cells (Ling et al. 1985, 1986, Miyamoto et al. 1985, Vale et al. 1986). Activins are homodimers of the $\beta$ subunits ( $\beta A$ and $\beta B$ ) and the different dimerization of subunits gives rise to three glycoproteins: activin $A(\beta A-\beta A)$, activin $B(\beta B-\beta B)$ and activin $A B$ ( $\beta A-\beta B$ ) (Mason et al. 1985). Similar to all TGF- $\beta$ members, activins are originally synthesized as larger precursor proteins which are subsequently cleaved to release the mature C-terminal protein.

Activins are secreted proteins and, as for any external stimulus, responsive cells must possess the proper mechanism to transduce the activin signal intracellularly (Attisano et al. 1996). Like most members of the TGF- $\beta$ family, activins mediate their actions by binding to a complex of transmembrane serine and threonine kinase receptors (Pangas \& Woodruff 2000). These activin receptors can be classified into two main categories, namely the type I receptor group, comprising the activin receptor-like kinase
(ALK2 and ALK4), and the type II receptor group comprising the activin type IIA and type IIB receptors (ActRIIA and ActRIIB) (Mathews 1994, Hoodless \& Wrana 1998).

The activins can bind to their individual receptor type II (IIA and IIB) when expressed alone, but fail to bind to the type I receptor in the absence of the type II receptor (Ebner et al. 1993). However, both receptor types are necessary to generate a high-affinity complex with activins, as well as for signalling (Wrana et al. 1994). The activated activin type I receptor propagates the signal through the phosphorylation of other proteins known as Smad proteins. The activated Smad complexes are transported into the nucleus and, in combination with other nuclear factors, they regulate the transcription of the target genes (Itoh et al. 2000, Attisano et al. 2001).

The structure and function of the uterine tube has received relatively little attention since the development of in vitro fertilization technology. Uterine tubes are biologically active, providing an environment that enhances and supports fertilization and early embryonic development as the embryo travels toward the uterine cavity (Tazuke \& Giudice 1996, Hunter 1998). In order to complete these events there is an embryonic-maternal dialogue in which the embryo and the maternal reproductive tract induce changes in each other to promote embryonic and endometrial maturation (Ghosh \& Sengupta 1998). 
Paracrine interaction between the uterine tube and the preimplantation embryo through growth factors, such as activin, has been suggested (Yoshioka et al. 2000). In addition to its role in the biology of the sperm (Boitani et al. 1995) and oocyte (Findlay 1993), a number of studies have suggested a role for activin and its receptors in early embryo development (Harvey et al. 1995). Most studies on the expression of inhibin-activin subunits in the uterine tube have been carried out in experimental animal species (Lu et al. 1993, Gandolfi et al. 1995). More recently the expression and secretion of activins and follistatin by the human endosalpinx has been reported in pre- and postmenopausal women (Bahathiq et al. 2002).

The role of uterine tube-derived activins is not yet known and the presence of activin in uterine tubes elongates the list of molecules potentially involved in early embryonic development. However, in order to support a paracrine or autocrine role for activins in specific tissue, both activin and its signalling components must be identified in this tissue. We therefore decided to study the expression and localization of inhibinactivin subunits and their receptors in the human endosalpinx.

\section{Materials and Methods \\ Patient recruitment and surgery}

Uterine tubes were obtained from ten women, undergoing routine total abdominal hysterectomy for benign disease not affecting the Fallopian tubes, at the Jessop Hospital for Women in Sheffield, UK. Before the operation, informed consent was obtained to perform unilateral or bilateral salpingectomy. This study was approved by the South Sheffield Research Ethics Committee. All women who donated Fallopian tubes had regular menstrual cycles and proven fertility with no evidence of tubal disease.

\section{Sampling and processing}

Immediately following hysterectomy, isthmic and ampullary regions of the excised tubes were identified, and a small section cut from each region using RNA-free equipment (baked at $200{ }^{\circ} \mathrm{C}$ for $4 \mathrm{~h}$ ). These samples were then cut into two equal pieces, with one piece being fixed in $10 \%$ buffered formalin for immunohistochemistry and the other part in $5 \mathrm{ml}$ RNAlater solution (Ambion, Huntingdon, Cambridgeshire, UK) for the RT-PCR. All the tissues used in the RT-PCR were snap-frozen in RNAlater solution and stored at $-20^{\circ} \mathrm{C}$ until used.

\section{Antibodies}

Monoclonal antibodies to detect the $\alpha$ subunit (R1) and the $\beta A$ (E4) and $\beta B(C 5)$ subunits of inhibin were obtained from Serotec Ltd (Oxford, Oxon, UK). Polyclonal antibodies to detect the ActRIIA (N-17) and ACTRIIB (N-16) were obtained from Santa Cruz Biotechnology Inc. (Santa
Cruz, CA, USA). Blocking peptides for the $\mathrm{N}-16$ and $\mathrm{N}-17$ polyclonal antibodies were obtained from Santa Cruz Biotechnology Inc.

\section{Immunohistochemistry}

An avidin-biotin horseradish peroxidase technique was used to localize the inhibin $\alpha, \beta A$ and $\beta B$ subunits and ActRIIA and ActRIIB following the protocol described previously (Bahathiq et al. 2002). Briefly, sections were dewaxed, dehydrated in alcohol and treated with $2 \%(\mathrm{v} / \mathrm{v})$ hydrogen peroxide for $20 \mathrm{~min}$ in methanol to block endogenous peroxidase (Streefkerk 1972). The sections used for the detection of inhibin $\alpha$ and $\beta B$ subunits and ActRIIA were pretreated in an $850 \mathrm{~W}$ domestic microwave oven in $0.01 \mathrm{M}$ citrate buffer for $10 \mathrm{~min}$. However, no pretreatment was required for the activin $\beta A$ subunit and ActRIIB. The sections were incubated for $30 \mathrm{~min}$ with normal horse serum and then incubated with the primary antibodies (the antibody concentrations were: 1:200 for C5 and N-16; 1:400 for R1, E4 and N-17) overnight at $4{ }^{\circ} \mathrm{C}$. The following day the sections were washed with $20 \mathrm{mM}$ phosphate-buffered saline $(\mathrm{pH} 7.3)$ and then incubated with 1:200 biotinylated anti-mouse (for R1, E4 and C5) and anti-goat (for N-17 and N-16) secondary antibody for $30 \mathrm{~min}$. After a further wash step, the sections were incubated with the avidin-biotin peroxidase complex ELITE system (Vector Laboratories Inc., Burlingame, CA, USA) for $30 \mathrm{~min}$ and then subsequently with 3, 3'-diaminobenzidine (Vector Laboratories Inc.) for $10 \mathrm{~min}$. Sections were washed in tap water, counterstained with Gill's haematoxylin, then dehydrated in a series of graded ethanol, cleared in xylene and mounted in DPX (BDH (Poole, Dorset, UK)/Merck (Darmstadt, Germany)). With regard to the $\mathrm{N}-16$ and $\mathrm{N}-17$ polyclonal antibodies, negative controls were designed by replacing each antibody by the corresponding blocking peptide. The same protocol was applied for the negative controls.

The sections were observed on a Labor Lux microscope (Leitz, Wetzlar, Germany), at magnifications of $\times 100$, $\times 250$ and $\times 400$. A positive reaction was characterized by the presence of brown staining. Each section was examined by two observers who agreed on the intensity of staining according to the following semi-quantitative scale: - , negative; \pm , equivocally positive; + , weakly positive; ++ , positive; +++ , strongly positive. Representative sections were photographed using an Olympus digital camera at $\times 250$ and $\times 400$ magnification.

\section{In situ hybridization}

This was performed using fluorescein-labelled cDNA oligonucleotide probes directed against mRNA encoding the activin $\beta A$ and $\beta B$ subunits in sections of human uterine tubes. The complete cDNA sequences of the $\beta A$ (gene identification, $\mathrm{Gl}={ }^{\prime 204936}$ ') and $\beta B \quad\left(\mathrm{Gl}={ }^{\prime} 186422^{\prime}\right)$ subunits were obtained from GenBank (National Institutes 
of Health, Bethesda, MD, USA). Human oligonucleotide probes complementary to the $\beta A$ subunit and $\beta B$ subunit comprised of 30 nucleotides each were obtained from Cruachem Ltd (Glasgow, UK).

The protocol was undertaken as described by Bahathiq et al. (2002). Sense probes specific for each of the subunits were used for control hybridizations and in every experiment a negative control sample was included for each set of conditions tested.

The sections were observed on a Leitz-labor Lux microscope at a magnification of $\times 400$. A positive reaction was characterized by the presence of nuclear purple staining. Representative sections were photographed using a Leica Wild MPS 48/52 Photoautomat (Leica, Heebrugg AG, Switzerland).

\section{RT-PCR}

Total RNA was isolated from human Fallopian tubes and rat ovaries as directed by the manufacturer using the RNAqueous-4PCR kit (Ambion) and subsequently treated with DNase 1 (Ambion) to remove any contaminating DNA. The approximate estimated weight for each tissue used was $15 \mathrm{~g}$.

The RNA samples were concentrated by the optional step included in the kit. Finally, the RNA samples were resuspended in $20 \mu \mathrm{l}$ elution solution and incubated for 5 min at $65^{\circ} \mathrm{C}$. The total RNA extracted was measured. The total RNA concentration of the human Fallopian tube was $1.47 \mu \mathrm{g} / \mu \mathrm{l}$ and that of the rat ovary was $0.40 \mu \mathrm{g} / \mu \mathrm{l}$.

RT using the RETROscript kit (Ambion) was carried out following the manufacturer's protocol. Briefly, RT was performed without heat denaturation of the RNA by adding $2 \mu \mathrm{g}$ total RNA from each sample under investigation (human Fallopian tube and rat ovary) and using random decamers.

The PCR was set up according to the manufacturer's manual (RETROscript kit). Two negative controls were included, one with minus RT control from the previous step and a minus template PCR, which contained all the PCR components but water was used as a template. PCR was carried out in $50 \mu \mathrm{l}$ total volumes with $4 \mu \mathrm{l}$ RT reaction products from step 1, $1 \cup$ DNA polymerase (SuperTaq-polymerase enzyme; Sigma, Poole, Dorset, UK) and primers (Metabion, Planegg-Martinsried, Germany) (Table 1) were used at $20 \mathrm{pmol}$ concentration. The PCR was carried out using the following cycle protocol: denaturation at $95^{\circ} \mathrm{C}$ for $4 \mathrm{~min}, 30$ cycles, each cycle divided into $94^{\circ} \mathrm{C}$ for $30 \mathrm{~s}$, annealing temperature $\left(60^{\circ} \mathrm{C}\right.$ for $30 \mathrm{~s}$ ) and $72^{\circ} \mathrm{C}$ for $1 \mathrm{~min}$, followed by final extension at $72{ }^{\circ} \mathrm{C}$ for $5 \mathrm{~min}$.

\section{Results}

\section{Immunohistochemistry}

Uterine tubes were obtained from ten premenopausal women in the luteal phase (median age, 37 years; range 31-45 years). Immunohistochemistry using a range of dilutions of antibody specific for the $\alpha$ subunit failed to demonstrate any positivity in any of the sections of the tube. However, positive staining was observed in all tissue samples for the inhibin $\beta A$ and $\beta B$ subunits (Fig. 1) as well as for ActRIIA and ActRIIB (Fig. 2 and Tables 2 and $3)$. In the present study, antibodies directed against activin $\beta$ A subunits (Fig. 1C and D) and ActRIIA (Fig. 2G and I) demonstrated immunoreactivity in both the ampulla and the isthmus. The antibody clearly labelled the cytoplasm of the tubal epithelial cells. All the epithelial cells were stained and the intensity of the immunoreaction decreased towards the isthmic region, showing a gradient of expression along the Fallopian tube. The immunoreactivity for the activin $\beta B$ subunits (Fig. $1 E$ and $F$ ) and ActRIIB (Fig. $2 \mathrm{H}$ and $\mathrm{J}$ ) showed a similar localization to the activin $\beta A$ subunits and ActRIIA. Of particular interest was that some of the columnar epithelial cells showed nuclear localization of both $\beta B$ subunit and ActRIIB whilst adjacent cells of similar morphology sometimes displayed no localization (Figs $1 \mathrm{~F}$ and $2 \mathrm{~J}$ ) (green arrows). The immunoreaction intensity again decreased towards the isthmic region with a gradient of expression along the tube. No immunoreactivity was observed by using blocking peptides against $\mathrm{N}-16$ and $\mathrm{N}-17$ polyclonal antibodies (Fig. 2E and F).

\section{In situ hybridization}

Figures 3 and 4 show the results of in situ hybridization of premenopausal uterine tube tissue and related controls for the $\beta A$ (Fig. 3) and $\beta B$ (Fig. 4) subunits. In both cases, positive staining shown by a purple colour (indicating the presence of mRNA) was seen associated with the tubal epithelial nuclei (Figs 3E and 4E). Two-week-old rat testes were used as positive control tissue for the $\beta A$ subunit (Fig. 3A) and human epididymal tissue was used as a

Table 1 Sequences of PCR primers used for detection of ActRIIA and ActRIIB in the human Fallopian tube and rat ovary.

\begin{tabular}{|c|c|c|}
\hline Primers for: & Forward & Reverse \\
\hline \multicolumn{3}{|l|}{ ActRIIA } \\
\hline Human & 5'TACTGCTGCAGATGGACCTG3' & 5'AGCTCCAGTTCAGAGTCCC $3^{\prime}$ \\
\hline Rat & 5'TACTGCTGCAGATGGACCTG3' & 5'AGCTCCAGTTCAGAGTCCC $3^{\prime}$ \\
\hline \multicolumn{3}{|c|}{ 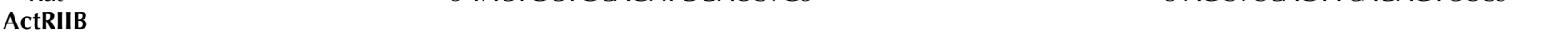 } \\
\hline Human & 5'ACACGGGAGTGCATCTACTTAC $3^{\prime}$ & 5'GGCAAATGAGTGAAGCGCTCG $3^{\prime}$ \\
\hline Rat & 5’ACTCGGGAGTGCATCTACTAC3' & 5'GGCAAATGGGTGAAGCGCTCG $3^{\prime}$ \\
\hline
\end{tabular}



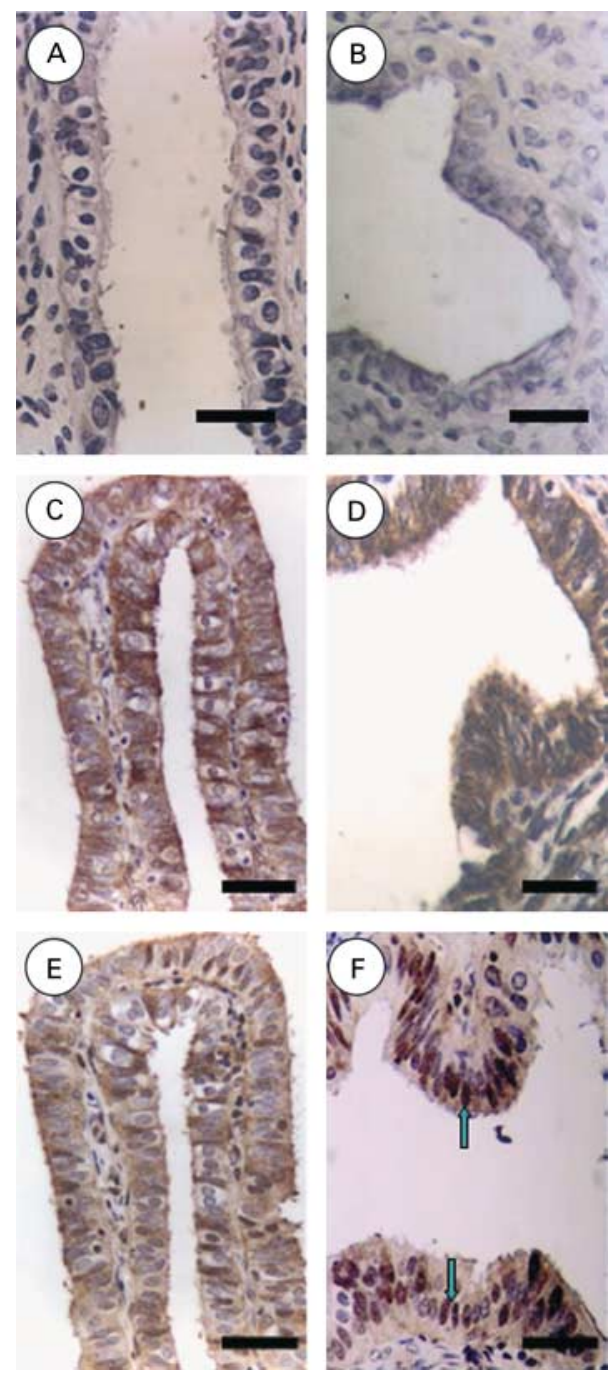

Figure 1 Immunohistochemical localisation of the (A and B) $\alpha$ subunit, $(C$ and $D)$ the $\beta A$ subunit and (E and $F)$ the $\beta B$ subunit in the ampullary (left-hand series) and isthmic region (right-hand series) of uterine tube sections from premenopausal women. (F) Nuclear staining using $\mathrm{C} 5$ antibody against the $\beta \mathrm{B}$ subunit (green arrows). (A and $B \times 250$ and $C, D, E$ and $F \times 400)$. Scale bars $=20 \mu \mathrm{m}(A$ and $B)$, $18 \mu \mathrm{m}(\mathrm{C}$ and $\mathrm{D})$ and $28 \mu \mathrm{m}$ (E and F).
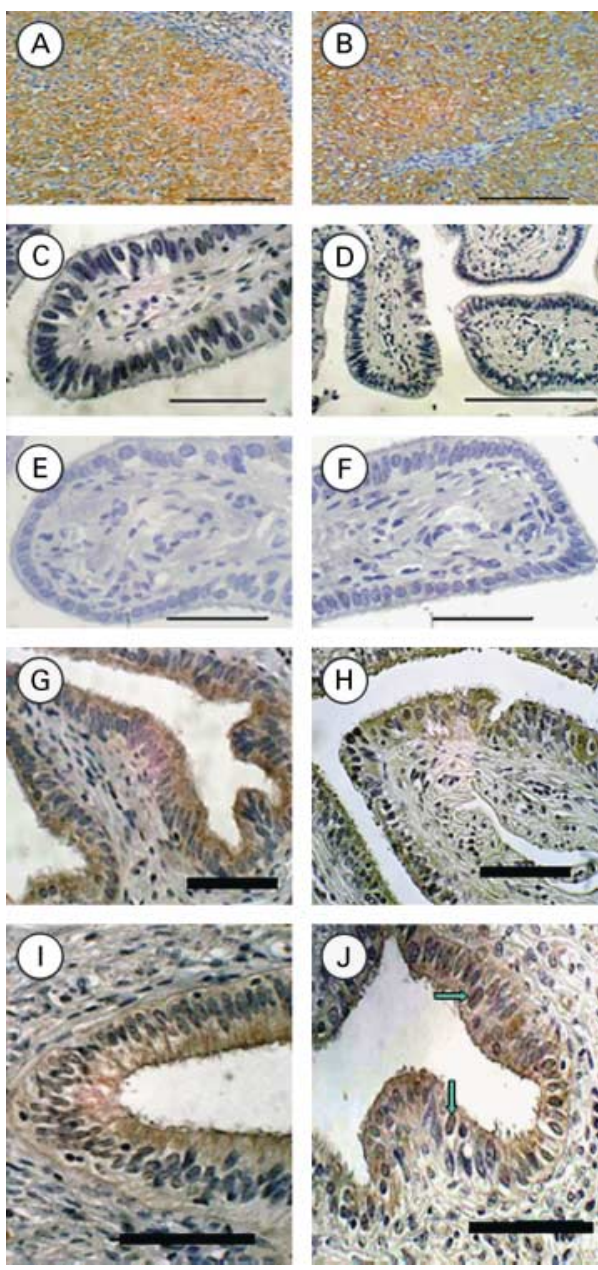

Figure 2 Immunohistochemical localization of ActRIIA (left-hand series) and ActRIIB (right-hand series) in the ( $\mathrm{G}$ and $\mathrm{H}$ ) ampullary and (I and J) isthmic areas of uterine tube sections from premenopausal women. Rat ovary was used as a positive control tissue for the (A) ActRIIA and (B) ActRIIB. No immunoreactivity was observed in negative controls, where ( $C$ and $D)$ refer to sections omitting the primary antibodies, while (E and F) refer to those using blocking peptide for ActRIIA and ActRIIB respectively. (J) Nuclear staining using N-16 antibody against ActRIIB (green arrows). (A, B, C, E, F, I and J $\times 400$, $\mathrm{G}$ and $\mathrm{H} \times 250$ and $\mathrm{D} \times 100)$. Scale bars $=5 \mu \mathrm{m}(\mathrm{A}, \mathrm{B}, \mathrm{G}$ and $\mathrm{H})$, $10 \mu \mathrm{m}$ (I and J), $7 \mu \mathrm{m}$ (C, E and F) and $15 \mu \mathrm{m}(\mathrm{D})$.

Table 2 Summary of the intensity of immunohistochemical expression of inhibin $\alpha, \beta A$ and $\beta B$ in ten premenopausal human uterine tubes. For each patient, both tubes were examined

\begin{tabular}{|c|c|c|c|c|c|c|c|c|c|c|}
\hline \multirow[t]{2}{*}{ Inhibin submit } & \multicolumn{10}{|c|}{ Patient number } \\
\hline & 1 & 2 & 3 & 4 & 5 & 6 & 7 & 8 & 9 & 10 \\
\hline \multicolumn{11}{|l|}{$\alpha$ subunit } \\
\hline Ampulla & - & - & - & - & - & - & - & - & - & - \\
\hline Isthmus & - & - & - & - & - & - & - & - & - & - \\
\hline \multicolumn{11}{|l|}{ BA subunit } \\
\hline Ampulla & +++ & +++ & ++ & +++ & +++ & +++ & +++ & +++ & +++ & +++ \\
\hline \multirow{2}{*}{\multicolumn{11}{|c|}{ BB subunit }} \\
\hline & & & & & & & & & & \\
\hline Ampulla & ++ & ++ & ++ & ++ & ++ & ++ & ++ & ++ & ++ & ++ \\
\hline Isthmus & + & + & + & + & + & + & + & + & + & + \\
\hline
\end{tabular}

For definition of scale see section on Immunohistochemistry in Materials and Methods. 
Table 3 Summary of the intensity of the immunohistochemical expression of ActRIIA and ActRIIB in ten premenopausal women.

\begin{tabular}{|c|c|c|c|c|c|c|c|c|c|c|}
\hline & \multicolumn{10}{|c|}{ Patient number } \\
\hline & 1 & 2 & 3 & 4 & 5 & 6 & 7 & 8 & 9 & 10 \\
\hline ActRIIA & & & & & & & & & & \\
\hline $\begin{array}{l}\text { Ampulla } \\
\text { Isthmus }\end{array}$ & $\begin{array}{c}+++ \\
++\end{array}$ & $\begin{array}{c}+++ \\
++\end{array}$ & $\begin{array}{c}+++ \\
++\end{array}$ & $\begin{array}{c}+++ \\
++\end{array}$ & $\begin{array}{c}+++ \\
++\end{array}$ & $\begin{array}{c}+++ \\
++\end{array}$ & $\begin{array}{c}+++ \\
++\end{array}$ & $\begin{array}{c}+++ \\
++\end{array}$ & $\begin{array}{c}+++ \\
++\end{array}$ & $\begin{array}{c}+++ \\
++\end{array}$ \\
\hline ActRIIB & & & & & & & & & & \\
\hline $\begin{array}{l}\text { Ampulla } \\
\text { Isthmus }\end{array}$ & $\begin{array}{c}++ \\
+\end{array}$ & $\begin{array}{c}++ \\
+\end{array}$ & $\begin{array}{c}++ \\
+\end{array}$ & $\begin{array}{c}++ \\
+\end{array}$ & $\begin{array}{c}++ \\
+\end{array}$ & $\begin{array}{c}++ \\
+\end{array}$ & $\begin{array}{c}++ \\
+\end{array}$ & $\begin{array}{c}++ \\
+\end{array}$ & $\begin{array}{c}++ \\
+\end{array}$ & $\begin{array}{c}++ \\
+\end{array}$ \\
\hline
\end{tabular}

The previous tables ( 2 and 3 ) represent the overall observtions of immunoreactivity and staining which were repeatedly consistent after experimentation with optimum antibody concentrations for the different inhibin subunits and ActRIIA and ActRIIB. For definitions see section on Immunohistochemistry in Materials and Methods.

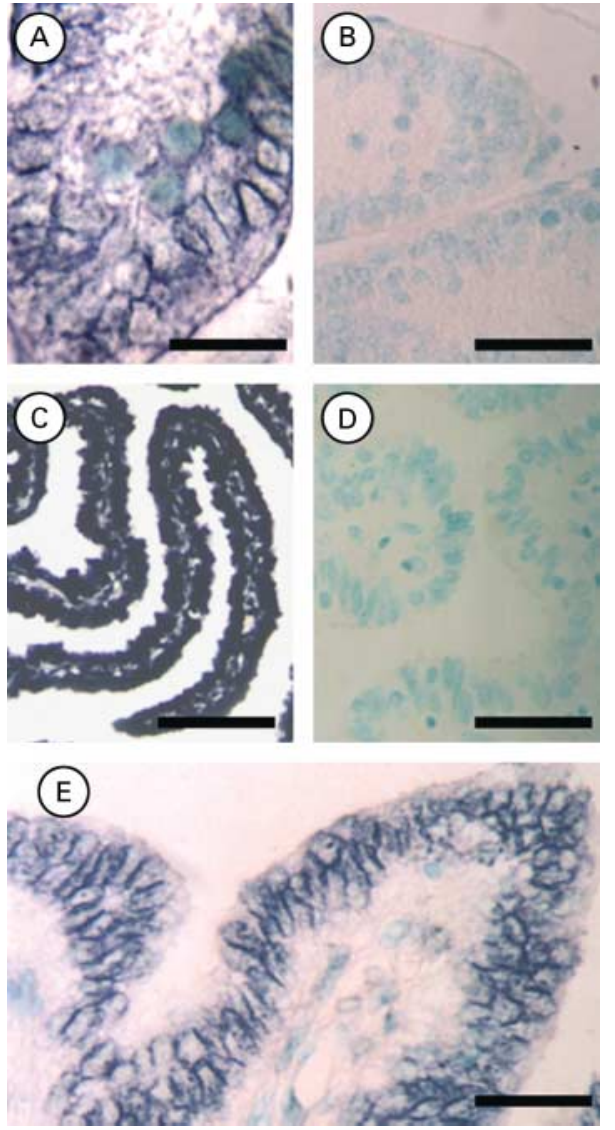

Figure 3 Localization of activin $\beta A$ subunit mRNA in tissue sections of Fallopian tube from premenopausal women showing mRNA localization in the nucleus of epithelial cells. (A) Rat testis incubated with anti-sense probe for $\beta$ A subunit (positive control), (B) rat testis incubated with sense probe (negative control), (C) human Fallopian tube incubated with Poly dT oligonucleotide probe, (D) human uterine tube incubated with hybridization buffer, $(E)$ human Fallopian tube incubated with anti-sense probe for $\beta$ A subunit. (A, D and $E \times 400$, $B \times 250$ and $C \times 100)$. Scale bars $=17 \mu \mathrm{m}(A, B$ and $D), 40 \mu \mathrm{m}(C)$ and $12.5 \mu \mathrm{m}$ (E).

positive control for the $\beta \mathrm{B}$ subunit (Fig. 4A). For both subunits, staining was absent in the negative controls (Figs $3 \mathrm{~B}$ and $\mathrm{D}, 4 \mathrm{~B}$ and $\mathrm{D})$. A Poly $\mathrm{d} t$ oligonucleotide probe was used to monitor the sample preparation and in both cases was positive (Figs $3 \mathrm{C}$ and $4 \mathrm{C}$ ).
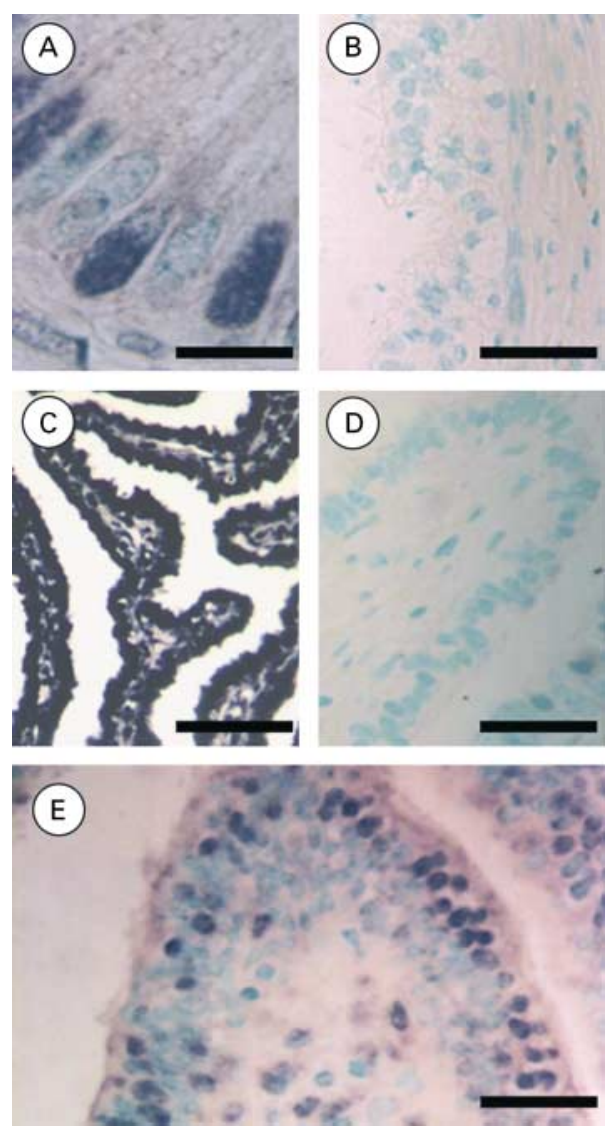

Figure 4 Localization of activin $\beta B$ mRNA in tissue sections of Fallopian tube from premenopausal women showing mRNA localization in the nucleus of epithelial cells. (A) Human epididymis incubated with anti-sense probe for $\beta B$ subunit (positive control), (B) human epididymis incubated with sense probe (negative control), (C) human Fallopian tube incubated with Poly dT oligonucleotide probe, (D) human Fallopian tube incubated with hybridization buffer, $(E)$ human Fallopian tube incubated with anti-sense probe for $\beta B$ subunit. (A $\times 1000, B, D$ and $E \times 400$ and $C \times 100)$. Scale bars $=7 \mu \mathrm{m}(A)$, $17 \mu \mathrm{m}(\mathrm{B}$ and D), $40 \mu \mathrm{m}(\mathrm{C})$ and $20 \mu \mathrm{m}(\mathrm{E})$.

\section{RT-PCR}

Running the RT-PCR samples on acrylamide gel showed amplicons of expected sizes corresponding to the ActRIIA (Fig. 5C and E) and ActRIIB (Fig. 5D and F). Amplified 


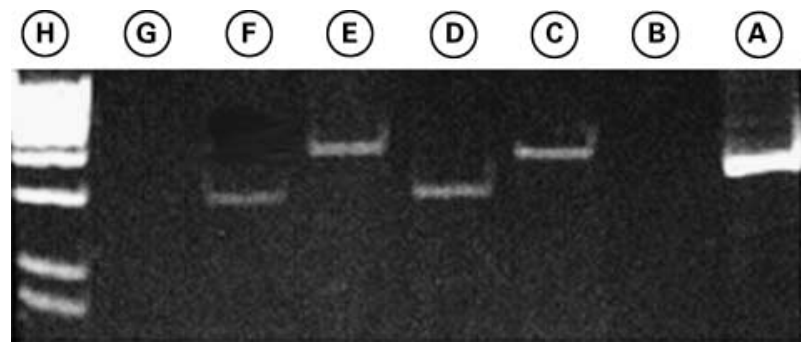

Figure 5 Examples of RT-PCR analysis of samples extracted from (C and D) human uterine tubes and ( $E$ and $F$ ) rat ovary, which was used as a positive control. The samples were amplified using primers specific for (C and E) ActRIIA and (D and F) ActRIIB. (A) The positive control provided by the manufacturer (Ambion) to ensure the quality of the PCR, (B) the minus RT negative control for ActRIIA, (G) the minus RT negative control for ActRIIB and $(H)$ the ladder.

products were found in all samples derived from human Fallopian tubes (Fig. 5C and D) and rat ovary (Fig. 5E and F). The samples from the human Fallopian tube showed the expected sizes for activin receptors shown by the rat ovary (435 bp for ActRIIA and $283 \mathrm{bp}$ for ActRIIB) with no genomic contamination as showed by the minus RT negative control (Fig. 5B and G).

\section{Discussion}

Inhibins and activins are classically defined by their regulation of FSH secretion from pituitary gonadotroph cells. Since its isolation in 1985, several studies concerning the distribution and possible physiological roles of activin in the reproductive tract have been made. In addition to its role in the biology of the sperm (Boitani et al. 1995) and oocyte (Findlay 1993), a number of studies have suggested a role for activin and its receptors in early embryo development (Lu et al. 1993, Yoshioka et al. 1998, He et al. 1999).

The present study is the first to identify the presence of ActRIIA and ActRIIB in the human endosalpinx (Fig. 2), and describes the expression and localization of activin subunits and their type II receptors along the endosalpinx. Whilst ActRIIA (Fig. 2G and I) and $\beta$ A subunit (Fig. 1C and D) showed ubiquitous cytoplasmic expression in the tubal epithelial cells, ActRIIB (Fig. $2 \mathrm{H}$ and J) and the $\beta \mathrm{B}$ subunit (Fig. 1E and F) demonstrated cytoplasmic and/or nuclear staining in a subpopulation of cells only (Figs $1 \mathrm{~F}$ and 2J) (green arrows), suggesting their expression by specific tubal epithelial cell subtypes. In addition, we found a correlation between the intensity of expression of the activin proteins (Fig. 1) with their type II receptors (Fig. 2) along the Fallopian tube. Both receptors were highly expressed in parallel with the activin subunits in the ampullary region (Figs $1 \mathrm{C}$ and $\mathrm{E}$ and $2 \mathrm{G}$ and $\mathrm{H}$ ), which is the site of fertilization, and comparatively less strongly expressed in the isthmic region (Figs $1 \mathrm{D}$ and $\mathrm{F}$ and $2 \mathrm{I}$ and $\mathrm{J}$ ).

As immunohistochemical analysis does not provide evidence of ability of cells to synthesize activin proteins and their type II receptors, other techniques were included. We performed in situ hybridization for activin $\beta A$ and $\beta B$ subunit mRNA and RT-PCR for ActRIIA and ActRIIB using the same tissue samples. The results of these experiments provided evidence that activin subunits and receptors are synthesized by the endosalpinx (Figs 3, 4 and 5).

With regard to a role for activin in the early embryonic development, mRNAs for activin $\beta A$ subunits, follistatins and type I and type II activin receptors have been shown to be expressed in bovine oocytes and embryos from the immature oocyte to the hatched blastocyst stages (Yoshioka et al. 1998). However, it has been suggested that early mouse and human embryos, from the four-cell stage to the morula stage, are unable to synthesize activins, as no mRNA for these proteins has been identified at these stages of development ( $\mathrm{Lu}$ et al. 1993, He et al. 1999). Furthermore, it has been proposed that activin, which binds to the activin type I and type II receptors on the preimplantation embryo, may be derived from the surrounding tissue such as the endosalpinx (He et al. 1999), and that the oocyte is capable of receiving an activin signal produced by surrounding cumulus cells, but not of transmitting one (Sidis et al. 1998). Moreover, it has been suggested that activin has a local paracrine or autocrine role with regard to early embryonic development as it is co-expressed with follistatin, the binding protein of activin, which would mitigate against tubal activin having a more distant site of action (Bahathiq et al. 2002).

This study agrees with previous observations, which have demonstrated co-expression of the activin subunits and their type II receptors in all tissues studied. Furthermore, recent studies in vitro have shown a relationship between the concentration of activin in embryo culture medium, fertilization and embryo development (Yoshioka et al. 1998, Mtango et al. 2003). The addition of activin A to presumptive matured and fertilized bovine zygotes increased, while the addition of follistatin decreased the percentage of zygotes that developed to morula and blastocyst stages (Yoshioka et al. 1998). However, the totality of cells in morula and blastocyst stages was not affected by the addition of activin A and/or follistatin. Additionally, a comparison between groups of bovine oocytes treated with activin and controls showed that there was an increase in the percentage of oocytes that reached metaphase II, developed to blastocyst and hatched, in groups treated with activin (Mtango et al. 2003). An ongoing study from our own unit has recently shown that activin and its type II receptors are amongst the first mRNAs synthesized by the activated human embryonic genome (K Morris \& K Martin, unpublished observations). Other studies have confirmed stage-specific expression, e.g. follistatin mRNA was expressed early in the gastrula stage of Xenopus embryos (Thomsen et al. 1990) and in periand postimplantation mouse blastocysts (Lu et al. 1993). A recent study in humans (He et al. 1999) has suggested that expression of $\beta$ A subunit, activin type I receptor and follistatin were hardly detectable in preimplantation 
embryos before the morula stage. Expression was noticeably increased at the blastocyst stage, demonstrating that the expression of the $\beta$ A subunit, activin type I receptor and follistatin was dependent on embryonic developmental stage.

Activins secreted by the epithelium may have a variety of functions. In addition to their potential effects on gamete or embryo development and maturation, activins may also act locally to regulate the activity of epithelial cilia and smooth muscle contractility. Both cilial activity and tubal peristalsis are believed to be necessary for successful transport of the immotile oocyte and later embryo along the tube to arrive at the endometrial cavity at the optimum time for adhesion and implantation. Little is known of the mechanism by which the process of embryo transport is co-ordinated within the tube, although it is critical for the successful establishment of pregnancy and avoidance of ectopic pregnancy. Further studies are now planned to assess the effects of TGF- $\beta$-derived growth factors on endosalpingeal and cilial function.

\section{References}

Attisano L, Wrana JL, Montalvo E \& Massaqué J 1996 Activation of signalling by the activin receptor complex. Molecular and Cellular Biology 16 1066-1073.

Attisano L, Silvestri C, Izzi L \& Labbé E 2001 The transcriptional role of Smads and FAST (FoxH1) in TGF- $\beta$ and activin signalling. Molecular and Cellular Endocrinology $1803-11$.

Bahathiq AO, Stewart RL, Wells M, Moore HD, Pacey AA \& Ledger WL 2002 Production of activins by the human endosalpinx. Journal of Clinical Endocrinology and Metabolism 87 5283-5289.

Boitani C, Stefanini M, Fragale A \& Morena AR 1995 Activin stimulates Sertoli cell proliferation in a defined period of rat testis development. Endocrinology 136 5438-5444.

Ebner R, Chen R-H, Shum L, Lawler S, Zioncheck TF, Lee A, Lopez AR \& Derynck R 1993 Cloning of a type I TGF- $\beta$ receptor and its effect on TGF- $\beta$ binding to the type II receptor. Science $\mathbf{2 6 0}$ 1344-1348.

Findlay JK 1993 An update on the role of inhibin, activin and follistatin as local regulators of folliculogenesis. Biology of Reproduction 48 15-23.

Gandolfi FM, Modina S, Brevini TAL, Passoni L, Artini P, Petraglia F \& Lauria A 1995 Activin $\beta$ A subunit is expressed in bovine oviduct. Molecular Reproduction and Development 40 286-291.

Ghosh D \& Sengupta J 1998 Recent developments in endocrinology and paracrinology of blastocyst implantation in the primate. Human Reproduction Update 4 153-168.

Harvey MB, Leco KJ, Arcellana-Panlilio MY, Zhang X, Edwards DR \& Schultz GA 1995 Roles of growth factors during preimplantation development. Human Reproduction $10712-718$.

He ZY, Liu HC, Mele CA, Barmat L, Veeck LL, Davis O \& Rosenwaks Z 1999 Expression of inhibin/activin subunits and their receptors and binding proteins in human preimplantation embryos. Journal of Assisted Reproduction and Genetics 16 73-80.

Hoodless PA \& Wrana JL 1998 Mechanism and function of signaling by the TGF beta superfamily. Current Topics in Microbiology and Immunology 228 235-272.

Hunter RH 1998 Have the Fallopian tubes a vital role in promoting fertility? Acta Obstetricia et Gynecologica Scandinavica 77 475-486.
Itoh S, Itoh F, Goumans M-J \& ten Dijke P 2000 Signaling of transforming growth factor- $\beta$ family members through Smad proteins. European Journal of Biochemistry 267 6954-6967.

Ling N, Ying S-Y, Ueno N, Esch F, Denoroy L \& Guillemin R 1985 Isolation and partial characterization of a Mr 32000 protein with inhibin activity from porcine follicular fluid. PNAS 82 7217-7221.

Ling N, Ying S-Y, Ueno N, Shimasaki S, Esch F, Hotta M \& Guillemin R 1986 Pituitary FSH is released by a heterodimer of the $\beta$-subunits from the two forms of inhibin. Nature 321 779-782.

Lu RZ, Matsuyama S, Nishihara M \& Takahashi M 1993 Developmental expression of activin/inhibin $\beta \mathrm{A}, \beta \mathrm{B}$ and $\alpha$-subunit and activin receptor type IIB genes in preimplantation mouse embryos. Biology of Reproduction 49 1163-1169.

Mason A, Hayflick J, Ling N, Esch F, Ueno N, Ying S-Y, Guillemin R, Niall H \& Seeburg P 1985 Complementary DNA sequences of ovarian follicular fluid inhibin show precursor structure and homology with transforming growth factor- $\beta$. Nature 318 659-663.

Massagué J 1990 The transforming growth factor- $\beta$ family. Annual Review of Cellular Biology 6 597-641.

Mathews LS 1994 Activin receptor and cellular signaling by the receptor serine kinase family. Endocrine Reviews 15 310-325.

Miyamoto K, Hasegawa Y, Fukuda M, Nomura M, Igarashi M, Kangawa K \& Matsuo H 1985 Isolation of porcine follicular fluid inhibin of $32 \mathrm{~K}$ daltons. Biochemical and Biophysical Research Communications 129 396-403.

Mtango NR, Varisanga MD, Dong YJ, Rajamahendran R \& Suzuki T 2003 Growth factors and growth hormone enhance in vitro embryo production and post-thaw survival of vitrified bovine blastocysts. Theriogenology 59 1393-1402.

Pangas SA \& Woodruff TK 2000 Activin signal transduction pathways. Trends in Endocrinology and Metabolism 11 309-314.

Sidis Y, Fujiwara T, Leykin L, Isaacson K, Toth T \& Schneyer AL 1998 Characterization of inhibin/activin subunit, activin receptors, and follistatin messenger ribonucleic acid in human and mouse oocytes: evidence for activin's paracrine signaling from granulosa cells to oocytes. Biology of Reproduction 59 807-812.

Streefkerk JG 1972 Inhibition of erythrocyte pseudoperoxidase activity by treatment with hydrogen peroxide following methanol. Journal of Histochemistry and Cytochemistry 20 829-830.

Tazuke SI \& Giudice LC 1996 Growth factors and cytokines in endometrium, embryonic development, and maternal:embryonic interactions. Seminars in Reproductive Endocrinology $\mathbf{1 4}$ $231-243$.

Thomsen G, Woolf T, Whitman M, Sokol S, Vaughan J, Vale W \& Melton DA 1990 Activins are expressed early in Xenopus embryogenesis and can induce axial mesoderm and anterior structure. Cell 63 485-493.

Vale W, Rivier J, Vaughan J, McClintock R, Corrigan A, Woo W, Karr D \& Spiess J 1986 Purification and characterization of an FSH releasing protein from porcine ovarian follicular fluid. Nature $\mathbf{3 2 1}$ 776-779.

Wrana JL, Attisano L, Wieser R, Ventura F \& Massagué J 1994 Mechanism of activation of the TGF- $\beta$ receptor. Nature 70 341-347.

Yoshioka K, Takata M, Taniguchi T, Yamanaka H \& Sekikawa K 1998 Differential expression of activin subunits, activin receptors and follistatin genes in bovine oocytes and preimplantation embryos. Reproduction, Fertility, and Development 10 293-298.

Yoshioka K, Suzuki C \& Iwamura S 2000 Effects of activin A and follistatin on developmental kinetics of bovine embryos: cinematographic analysis in a chemically defined medium. Journal of Reproduction and Fertility 118 119-125.

Received 24 December 2003

First decision 8 March 2004

Revised manuscript received 24 April 2004

Accepted 4 May 2004 